\title{
Gustav Metzger: Iconoclasm and Interdisciplinarity
}

Elizabeth Fisher

"To save society men must act beyond their professional disciplines, in fact must use their professions to change society. To go on limiting oneself to achievement strictly within the rules of a profession laid down by a society that is on the point of collapse, is to me a betrayal." (Metzger 1965, 3)

Gustav Metzger said this to an audience gathered at the Architectural Association in London in July 1965. They had come for one of his lecture/demonstrations on autodestructive art - the theory and practice of which he had been propounding since the early 1960s. Auto-destructive art was, on the face of it, a spectacular and provocative form of art as social commentary, a protest against the development of ultimately destructive technologies such as nuclear weapons, cars, pesticides and other industrial sources of environmental pollution. It took its cue from emerging forms of conceptual and performance art to challenge the notion of the autonomous art object, intervene in public spaces and extend the agency of art within society. Unlike traditional art forms, it required an interdisciplinary and collaborative approach and called for the skills, materials and expertise of scientists and engineers.

Between 1960-65, the lecture/demonstration became Metzger's primary vehicle for both testing his ideas and reaching an audience. As he made clear to his audience at the Architectural Association, Metzger saw auto-destructive art as a movement and he was looking for others - particularly those involved in an interdisciplinary and socially engaged practice such as architecture - to "join in this direction" (Metzger 1965, 2). 


\section{The conscience of the art world}

Gustav Metzger has been described as "the conscience of the art world" (Walker 2002, 31). His political commitments and personal ethics have played an important part in directing the course of his artistic development, leading him to explore alternative contexts and ways in which to operate as an artist. His activities have encompassed editorial work and political activism, curating and organising symposia, writing and research alongside innovative artistic forms including performative lecture/demonstrations, kinetic sculpture and some of the earliest light projections in the UK. His output from the late 1950s onwards reflect an evolving theory of art as both aesthetic form and social action, and make him a key precursor of activist art. ${ }^{1}$

Metzger's early childhood as an orthodox Jew in Nuremberg in the 1930s left him acutely politicised. In 1939, he escaped with his brother on the Kindertransport to England, leaving the rest of his family behind. In his early twenties, working in a furniture factory in Leeds, he became immersed in radical left-wing politics. There, he was involved with a Trotskyist workers' union and absorbed the theories of Marx and the philosopher and "natural living experimenter,", Edmund Szekely. He discovered Eric Gill's anti-capitalist writings on art and industrial society, which inspired him to seek work as a gardener at Harewood in 1943, then at Champneys, "a kind of naturecure heaven" where he encountered the writings of Willhelm Reich ${ }^{3}$. Through Reich, he read Freud. He moved to Bristol in 1944 and spent six months in an anarchist community, and although it left him disenchanted with the relationship between power and politics, these experiences fuelled his desire to become an artist; "one who cannot accept the way things are, who has to use his whole life, including his art, to change the world, society" (Phillpot and Metzger, 1997a) 
Between 1945-53, Metzger studied with the artist David Bomberg at Borough Polytechnic in London. Bomberg encouraged wide-ranging interests in art and architecture, and gave Metzger a thorough grounding in the history of modernism. Bomberg, who was himself deeply concerned with the relationship between art and society and expected the same of those around him, "urged his students to consider both revolutionary form and content." As Kristine Stiles notes, he "taught Metzger that the revolutionary formalism that had been unanimously upheld as the standard for radical art since Impressionism was insufficiently concerned with revolutionary content." ${ }^{4}$ In 1997, Metzger went as far as to describe the trajectory of his own ideas “as a continuation, an extension of Bomberg's." He recalled "a profound interaction between my ongoing development as an artist and my status as a favourite of Bomberg... He was all about a response. The first teaching was to respond to life, life outside. A concern to sharpen your intuition as much as your knowledge and to be a good person" (Phillpot and Metzger, 1997c).

In 1953, Metzger left Bomberg's circle and moved to King's Lynn. He set up a studio in an old warehouse, supporting himself as a second-hand book and furniture dealer. He became increasingly involved in political activism, specifically in direct action and other forms of resistance to the developments of post-war capitalist society. Metzger's targets ranged from the proliferation of nuclear weapons and the chaos of Cold War politics to the commodification of art. He established the King's Lynn CND group and spearheaded the King's Lynn North End Protest against the gentrification of the town's traditional fishing quarters. He was heavily involved in the Direct Action Committee Against Nuclear War, and took part in the 1959 Aldermaston March. He was a co-founder of the Committee of 100, and in 1961 
served a prison sentence for civil disobedience as a consequence of participating in direct action protests. ${ }^{5}$

In terms of making art, he gradually abandoned traditional techniques and materials, and began to move away from the production of actual objects. He mounted small exhibitions in King's Lynn, the focus of which marked the emergence of two critical concerns: the relationship between art and society, and the role of destruction in creation. The first exhibition was little more than a display of posters (there were twelve different designs) for the seminal exhibition, This is Tomorrow, at the Whitechapel Gallery in London in 1956. Organised by the architect and writer Theo Crosby with members of the Independent Group, the exhibition included over forty artists, architects, designers and theorists working in collaboration as twelve small, interdisciplinary groups to produce installations that incorporated new and massproduced materials, images and objects - expounding ways in which art could be inserted into the structures of modern society and daily life. Metzger visited the exhibition repeatedly and collected posters to redisplay in the street front windows of his shop/studio space at 30 Queen Street in King's Lynn. In 1957, he brought together sacred artefacts that had been mutilated and defaced during a period of iconoclasm between the English Reformation in the 1530s and the Commonwealth of 1649-1660, in an exhibition entitled Treasures from East Anglian Churches presented in the Crypt at Clifton House, also on Queen Street, as part of the King's Lynn Arts Festival. The relics, rather than being diminished, had acquired greater symbolic value as a result of the destructive efforts of the Protestant reformers. This exhibition established a dialectical dynamic that found expression in the relationship between auto-destructive and auto-creative art which developed over the following decade and has remained at the core of Metzger's ongoing practice. 


\section{Auto-Destructive, Auto-Creative}

On 4 November 1959, Metzger published his first manifesto. It was printed on a broadsheet produced to accompany the exhibition of Cardboards, selected and arranged by G. Metzger at 14 Monmouth Street, London. On display were a selection of discarded pieces of cardboard, presumed television packaging, cut and folded by machine for a strict purpose and unadulterated by the artist except insofar as having displayed them with the aim of emphasizing their formal qualities. At the top of the page, in a short text describing the exhibition, Metzger declared "These cardboards are nature unadulterated by commercial considerations or the demands of the contemporary drawing room. They have reference to the greatest qualities of modern painting, sculpture and architecture. ${ }^{, 6}$ Having established parity between the formal qualities of natural and machine-produced objects and the artistic achievements of modern masters, Metzger introduced a variation on this aesthetic paradigm, in the form of the first manifesto of Auto-Destructive Art.

Auto-destructive art could be "machine produced and factory assembled" in that it shared the formal qualities of found objects and unadulterated nature, but it was "primarily a form of public art for industrial societies." It had a limited lifespan; it could last seconds or decades, but it was not permanent, instead harnessing processes of change. It borrowed the event-structure of performance art and involved "a total unity of idea, site, form, colour, method and timing of the disintegrative process," recalling Walter Gropius' vision of "architecture, sculpture and painting in one unity" in the utopian Bauhaus manifesto of 1919.

In many ways, Metzger took his lead from the early twentieth century avantgarde. The closer integration of artists with science and industry had been a 
fundamental tenet of Constructivism; it had underpinned the radical educational philosophy of the Bauhaus and inspired the pioneering use of plastics in the kinetic art of artists Lazlo Moholy-Nagy and Naum Gabo among others. At the same time, the form of the manifesto itself had been an important platform for mobilising avantgarde movements from Dada to the Futurists. Moholy-Nagy in particular was an important reference point for Metzger, who perhaps thanks to Bomberg, saw his task as taking up the baton of the revolutionary avant-garde. In a seminal article on automata written in 1969, Metzger quoted Moholy-Nagy: “This is our century: machine-technology-socialism. Come to terms with it, and shoulder the tasks of the century." (Metzger 1969, 108)

In the sprit of the Constructivists, Metzger put cross-disciplinary collaboration at the heart of his manifesto: "The artist may collaborate with scientists, engineers" (Metzger 1959). Less than six months prior to this, the British scientist and novelist CP Snow had re-ignited public debate over perceived differences between the arts and sciences with his lecture, The Two Cultures and the Scientific Revolution. ${ }^{8}$ Metzger saw his opportunity. He approached the English critic Lawrence Alloway, then director of the Institute of Contemporary Arts, asking for help to establish contacts between artists and scientists. The requested help was not forthcoming, but Metzger found a like-minded supporter in the form of assistant director Jasia Reichardt, who introduced his first demonstration of auto-destructive art at the Temple Gallery in June 1960. ${ }^{9}$ In an article published in 1962, Metzger went further: "The study and appreciation of Machine Art involves technology, sociology, psychology and other branches of knowledge. The next step in Machine Art is the entry of the artist into factories..." (Metzger 1962a). His calls to foster interdisciplinary exchange pre-dated 
high-profile projects such as Experiments in Art and Technology (E.A.T., 1966) and John Latham's Artist Placement Group (1966) by several years.

The Auto-Destructive Art manifesto marked the start of a particularly intense period in which his activism and artistic practice became increasingly intertwined. The manifesto played a central role in articulating this; by 1964, Metzger had produced five manifestos. His second manifesto, Manifesto Auto-Destructive Art (10 March 1960), served to embed a clear anti-capitalist, anti-war message. As a response to "the immense productive capacity, the chaos of capitalism and of Soviet communism, the co-existence of surplus and starvation...the disintegrative effect of machinery and of life in vast built-up areas on the person," auto-destructive art was to "re-enact the obsession with destruction," “demonstrate man's power to accelerate disintegrative processes of nature and to order them," and "mirror the compulsive perfectionism of arms manufacture." Auto-destructive art would achieve this through "the transformation of technology into public art" (Metzger 1960). Listing examples of materials and techniques - from ballistics and cybernetics to nuclear energy - that could be used to create auto-destructive art, Metzger firmly located this new art form in a field of enquiry that aligned the artist with scientists and engineers and attempted to open a conversation between scientific research and artistic practice. Autodestructive art would not produce permanent objects and could not be manipulated by the art market. It was conceived for a new society forged, as Harold Wilson put it, in "the white heat" of a scientific revolution. ${ }^{10}$

The third manifesto, dated 23 June 1961, began by reiterating the aesthetic principles of the first manifesto. "Each visible fact absolutely expresses its reality. Certain machine-produced forms are the most perfect forms of our period. In the evenings, some of the finest works of art produced now are dumped on the streets of 
Soho" (Metzger 1961). This last line referred specifically to bags of textile offcuts, which, like the Cardboards, had been thrown out by the fashion houses along Great Marlborough Street. Metzger collected these bags and presented them as objets trouvés at a number of events in the early 1960s. (insert Fig. 1 anywhere between

\section{the start and this point)}

Echoing the format of the first manifesto, Metzger moved swiftly on to introduce Auto-Creative Art in the fourth line. In contrast with auto-destructive art, "an attack on capitalist values and the drive to nuclear annihilation," auto-creative art was described as "art of change, growth, movement." Deploying the same materials and processes, both auto-destructive art and auto-creative art, according to Metzger, aimed "at the integration of art with the advances of science and technology." Autocreative art, unburdened by the weight of political critique, allowed Metzger to pursue a broader spectrum of aesthetic experiences, defining a new role for the artist in relation to the work of art (further removed from the act or gesture itself), and a new form of art. "The immediate aim" he wrote, "is the creation, with the aid of computers, of works of art whose movements are programmed and can include 'selfregulation" (Metzger 1961).

"Artist acts in a political framework whether he knows it or not. Whether he wants to or not. The quantity of experience the artist has to pack into a work is so vast now, it is not possible to compress it all into the space of an object" wrote Metzger in Manifesto World, his fourth manifesto, on 7 October 1962. Written in the context of "a world on edge of destruction," just days before the Cuban Missile Crisis, Metzger also used the manifesto to lambast the bourgeois art world and the inadequacy of object-based art in the face of such reality. "Artist cannot compete with reality. [...] Artist cannot integrate within himself all the experiences of the present. He cannot 
render it in painting and sculpture." He concluded "It is a question of a new artistic sensibility" (Metzger 1962b).

By September 1964, in his fifth manifesto, On Random Activity in Material/Transforming Works of Art, Metzger had arrived at the all-encompassing term "material/transforming art." The self-regulation posited in the third manifesto (1961) and the new artistic sensibility suggested in the fourth finds expression as molecular theory and random activity in the fifth. The artist's relation to the work is explained thus: "At a certain point, the work takes over, is in activity beyond the detailed control of the artist, reaches a power, grace, momentum, transcendence... which the artist could not achieve except through random activity" (Metzger 1964). Ranging from nuclear annihilation to random molecular activity, Metzger's manifestos define art as the world as he experienced it and vice versa.

The same period (1959-64) saw Metzger experimenting with new materials and techniques, developing an aesthetic lexicon that drew on scientific ideas, and required engineers, computer programmers and scientists as advisors and collaborators. He began to develop proposals for public art works such as Model for an Auto-Destructive Monument (1960), which relied on a principle and technique "suggested by Mr E. Ll. Evans, who worked in the corrosion of metals research group at the National Chemical Laboratory" (Metzger 2015, 19) and the unrealized Five Screens with Computer (1965-9), a complex, ambitious proposal developed in consultation with different people at different stages, the first of whom was Beverley Rowe, then Head of Applications at the University of London Computing Centre. Another key technique developed during this time involved a chemical reaction between hydrochloric acid and the synthetic fabric, nylon. 
On 3 July 1961, dressed in protective gear including a gas mask, Metzger performed Recreation of First Public Demonstration of Auto-Destructive Art on the South Bank in London. ${ }^{11}$ It was a guerrilla intervention in public space without official sanction; Metzger had originally proposed it in response to an invitation from the architect \& writer Theo Crosby to participate in the International Union of Architects (IUA) summer conference on the theme of "the architecture of technology." When the IUA withdrew its support at the last minute, Metzger went ahead with the event, helped by a team of architecture students. In a broadsheet that was handed out to bystanders at the event, also known as his third manifesto, which included his third manifesto Auto-Destructive Art Machine Art Auto-Creative Art alongside the first two manifestos, he described the work thus:

“Acid action painting. Height 7', Length 12' 6". Depth 6'. Materials: nylon, hydrochloric acid, metal. Technique. 3 nylon canvases coloured white black red are arranged behind each other, in this order. Acid is painted, flung and sprayed onto the nylon which corrodes at point of contact within 15 seconds" (Metzger 1961) (insert Fig. 2 near here)

Metzger had moved from making recognisable 'paintings' with oil paint on various supports such as cardboard and steel in a studio to executing the same actions with different materials in a public setting. He had switched attention from the object to the event of painting itself, and turned a simple chemical reaction into a symbolic act on several levels. In 2009, Metzger recalled, "I was very aggressive putting the acid onto that nylon ... it was partly me attacking the system of capitalism, but inevitably also the systems of war, the warmongers, and destroying them in a sense symbolically.",12 
Metzger was at odds with the uncompromisingly self-referential modernist agenda of American Abstract Expressionism, not least for its association with U.S. foreign policy and the rhetoric of capitalism during the Cold War. Its influence had effectively embedded the notion of the autonomy of the art object within critical discourse and served to disengage art from any extraneous social context. Metzger's evolving praxis was one of many forms of resistance - from Gutai in Japan to Fluxus in Darmstaadt and New York - to the relationship between art and capitalism, and to the potentially perilous notion of 'disinterested' appreciation of the autonomous art object.

Working with new materials, forms, and drawing on spheres of expertise beyond the traditional scope of art, Metzger saw a way to repudiate the notion of art's autonomy and reinstate its social function. Between 1959-72, he produced a number of auto-creative and auto-destructive art works. Some, like the acid-action painting revealed an explicitly political position; others expressed his radical aesthetic agenda. Underpinning everything was a desire for revolutionary change, in artistic and social realms. "Auto-destructive art seeks to be an instrument for transforming people's thoughts and feelings, not only about art, but wants to use art to change peoples' relation to themselves and society" Metzger told an audience assembled at the Architectural Association in 1965 (1965, 3). In works that included unrealised proposals for public art works that corroded or disassembled themselves, light projections through various fluids to capture effects such as Brownian motion, and kinetic sculpture-as-event, Metzger harnessed the physical properties of materials, chemical reactions and natural forces to establish an aesthetic of transformation, which embodied the rhetoric of revolutionary change at a symbolic level. 
Alongside and in tandem with these works and his manifestos, Metzger was developing the hybrid format of his lecture/demonstrations, which as Andrew Wilson has noted, became a critical platform to contextualise and test his theories in front of audiences (Wilson 2008, 187). ${ }^{13}$ He adapted the template of a traditional academic lecture to develop a mode of artistic enquiry and production that also challenged the conventions of knowledge production, confronting the historical conditions and methodologies of public discourse. In this, he was a pioneer. Today, the lecture/demonstration or lecture/performance is seen as a sub-genre of Performance Art, a form of institutional critique, and its proliferation and theorisation is well documented. ${ }^{14}$ Metzger's lecture/demonstrations pre-date many other significant examples of the genre, including Robert Morris' 21.3 (1964), Joseph Beuys' Information Action (1972) - which Metzger attends - and Dan Graham's Performer/Audience/Mirror (1975).

While Metzger's lecture/demonstrations developed as a reflexive art form blending radical aesthetics, rhetoric and activism, they were nevertheless, as Wilson points out, "manifesto-as-form" (Wilson 2008, 178) - essentially vehicles for a political message. Metzger adapted the particular performance techniques and pedagogical function associated with the lecture format, and added elements such as moving image projections, installations, and live actions, significantly enhancing the perceptual experience in order to convey this message. He presented audiences with techniques still in development and ideas as detailed propositions for unrealised (and unrealisable) public art works, putting greater emphasis on the hypothetical and the work-in-progress. Occasionally Metzger created a complete visual environment for his lecture/demonstrations. His second lecture/demonstration, hosted by Cambridge University Heretics Society at Trinity College in 1960, included an elaborate 
installation of all his Cardboards, several Bags suspended from the ceiling and a miscellany of metal 'forms' plundered from skips around the university. He also covered the walls of the hall with the pages of that day's newspapers.

Between his first lecture/demonstration at the Temple Gallery in 1960 and "The Chemical Revolution in Art" at the Engineering School of the University of Cambridge in 1965, the format developed into a multi-layered event. Crucially, it provided Metzger with access to industrial-quality slide projectors, which enabled him to develop a range of startling visual effects. In February 1963, he incorporated his first light projection in a lecture at the Bartlett School of Architecture. Instead of a photographic slide, Metzger inserted a slide covered with nylon and painted with hydrochloric acid, so that the process of dissolving nylon was magnified and illuminated by the light of the projector. Metzger's innovative light projections evolved rapidly and by late 1965 , they had become complex, spectacular visual events. That year, at a benefit event for the ICA held at the Theatre Royal in Stratford, London, organised by the artists Mark Boyle and John Latham, Metzger used three large theatre projectors and a rear projector to project a variety of images simultaneously or in quick succession onto a large screen that spanned the entire stage.

Among the techniques he demonstrated, a circuit board used to build electronic equipment, was dipped in water and sprayed with graphite then inserted into the projector, which resulted in a "complex, always changing, very fast moving image." (Fig. 3 near here) He used the circuit board in combination with laboratory tubes partially filled with glycerine: "A glass rod, almost as wide as the tube was slowly plunged into the tube. The glycerine was forced upwards in continuous motion. When projected through the hundreds of tiny holes, each of which was a 
water-filled prism - sensational. Endless unrepeatable change." ${ }^{15}$ In another technique, black ink droplets fell into slide-shaped vials wedged between the projector bulb and lens and filled with water mixed with glycerine to slow down the dispersal of the ink. Metzger varied the effects by moving the lens forward and back. Such a projection of moving, changing images, he recalled, "Had never been seen before (in London). The audience seemed shocked" (Stiles 1987, 170).

Soon after the ICA benefit, Metzger was invited to give a second lecture/demonstration in Cambridge, this time at the invitation of the student-run Society of Arts. This lecture/demonstration, known as the "Chemical Revolution in Art" took place in November 1965; architecture student Robin Nicholson was responsible for organising the event, which turned out to be the most ambitious ever, including ten different light projection techniques. (Fig. 4 near here) Metzger decided the event in Cambridge was his opportunity to pursue something he'd read about liquid crystals in the August 1964 issue of Scientific American, and asked Nicholson to put him in touch with a scientist. Nicholson made contact with the protein chemist and immunologist Arnold Feinstein through his Feinstein's wife, the poet Elaine Feinstein. ${ }^{16}$ Metzger brought some liquid crystal samples that he'd obtained from the chemical company, Merck, and Feinstein helped Metzger develop a technique to manipulate the liquid crystals in such a way as to produce constantly changing visual effects, which he attempted (unsuccessfully) to demonstrate as part of "The Chemical Revolution in Art" lecture/demonstration. Within weeks Metzger had mastered the technique and presented a successful iteration of the liquid crystal technique at Better Books in London. He continued to use liquid crystals in lecture/demonstrations and exhibitions, eventually creating Liquid Crystal Environment, a large-scale installation work with five projections, conceived for an 
exhibition in 2005. (Fig. 5 near here) According to Metzger, the liquid crystal work had come to an end decades earlier, "with a clearly worked out project for a kind of meditation centre a renewal ground for people entirely based on liquid crystal. I discussed this in the early 1970s...with Cedric Price in his office, and again with Frank Popper in his office in December 1982 when he wanted me to show it at the Elektra Exhibition 1983.” (Stiles 1987, 184)

In 1966, the Benedictine monk and concrete poet Dom Sylvester Houedard wrote the only published description of one of Metzger's light projection demonstrations, in which the psychedelic is clearly implied:

"1. Polarizers in crossed position: insertion of liquid crystals: the effect as I remember is gentle wavering between slightly coloured intensities of light paler than even hand-tinted Bombay films

2. "two pieces of perforated metal" add water: move in relation to each other: this was dramatic and exactly the effect I aimed at in one of the kinetic poems conceived (still unmade) for the Cambridge 64 kinkon - a multi-flip like lighting up skyscraper - windows in controlled random-pattern rhythms 3. 'copper mesh with water: this dries out in heat of projector lamp add graphite to mesh: add glycerine: fast motion of graphite particles: yet this registered as a tamer experience

4. 'ink dripped into plastic containers filled with water: water at times mixed with glycerine: inverted gravity showed these beard forms mushrooming upwards - rigid control bouncing it off the invisible edges - elusive semifreedom of a live Rorschach blot - elusive menace as it closes in to totally fill square lighted area \& destruct all available counter-space - then blast of emerging into outer-counter-space as container is removed from projector - 
reminded of ambiguous psycho-sensation (birth trauma?) cathartic collapse of scenery in le balcon

5. 'projection of liquid crystals imprisoned between 2 thin sheets of glass: used with 2 pieces of polaroid: images made very quiet impact - I became acutely conscious this was like TV-screen - but bringing nothing in from outside why not use this in a flick-a-disc - would a William palmer be lit like this? 6. 'microscope slide burned \& melted with gas flame': is this what arson's pleasure means? The decoiling purity of the black wisp was a suprematis \& relentless death - caress, - bearable only because beautiful \& too quick 7. two pieces of perforated plastic: water: move in relation to each other: some use of polaroid: this was the moment of op beauty 8.1 liquid crystals: heat by gas flame: no Polaroid: chemical bubble mild colour change

8.2 liquid crystals: heat by gas flame: with Polaroid: chemical melts - rapid change from intense colour to total black out of field

8.3 liquid crystals cooling: with Polaroid: slow return of colour: formation of little close packed 4 leaved clovers like crosses or flowerbuds in islands of colour: these buds pirouette every time on piece of Polaroid is rotated - no sense of illusion like n. 7 - this is nature not magic - a new world it is still part of our solar system - like cosmonauts looking over to this planet of flowerbud continent - a strategy map covered with kinetic stickpins - I can accept the projector now as telescope or microscope - not as magic lantern - yes psychologically was this destruction? This inviting glimpse before it cooled too far of a humanly habitable Barbarella space-world could always be repeated with the same apparatus - the same crystals even not identically $\&$ in 
that sense it did extend the range of a Frank Malina or Ninocalos machine nothing was destroyed except replaced heat - of all 8 events $4 \& 6$ were the only ones that achieved beauty thru real destruction - this was the point to be reminded that the announced titled included 'auto-constructed-art - this n.8 was the event illustrated in the 10 Jun weekend Telegraph where Mario Amaya (who was unable to take part in the symposium) is actually made to say 'It really should be called auto-constructive' - the destruction of form thru change was to be a key to the entire discussion.

It was a cinema-like art form - a public art with all the eroticism of people sitting in a dark room confronted by light and shadows moving over a screen giving a direct physical impact often very rigorous. It was also theatrical in the rapport between Metzger's activities and the resulting projection metamorphoses of shapes - auto-creative tradition of Arcimboldo, Erasmus, Darwin, de Loutherbourg, Pere Castel, Scriabin, Moholy-Nagy, Agam. Sometimes parts of what seemed to be like part of improvisation were quite rigorous - a kind of moiré effect of two superimposed grids - their more sensuous parts were produced toward the end by the liquid crystals and polaroid.”(Houédard 1966) (Fig. 6 near here)

At the Architectural Association in July 1965, Metzger used the lecture/demonstration to align artistic praxis with political action. He declared "Auto-destructive art is a comprehensive theory for action in the field of the plastic arts in the post-second world war period. The action is not limited to theory of art and the production of art works. It includes social action. Auto-destructive art is committed to a left-wing 
revolutionary position in politics, and to struggles against future wars" (Metzger $1965,1)$.

Architecture had been an important influence for Metzger - from the medieval architecture of his childhood in Nuremberg to seminal encounters with Alison and Peter Smithson's work in the early 1950s. When he was living in King's Lynn, the Smithson's first major public building, Hunstanton Secondary School (1954), was being built just down the road. Effectively a manifesto for Brutalism, their ideological and ethical approach appealed to Metzger, who visited the building repeatedly during its construction. The Smithsons were also participants in the seminal, and for Metzger, highly influential, exhibition This is Tomorrow.

Architects therefore represented an important audience for Metzger, who saw not only opportunities to intervene and instigate revolution within the social fabric through the built environment, but also to exploit new materials and technologies on a spectacular scale. In an article published in Ark in 1962, Metzger described the London Transport Electricity Substation at Elephant \& Castle as "one of the most advanced forms of Auto-Creative Art in existence." He continued "The walls of this building are composed of over 800 identical pressed stainless-steel panels. The panels were shaped to the architect's specifications and are highly reflective. The building is seen by thousands of people day and night, often from vehicles in motion. It creates an enormous quantity of significant images through spectator participation, sunlight, atmospheric conditions, vehicle lights and street-lighting. This great work of art is far more than an elaborate light reflector. It proves beyond doubt that only the collaboration of the artist and technology and the use of machine forms can give us certain experiences we need" (Metzger 1962a). 
Equally, Metzger's ideas about random and auto-destructive processes, revolutionary social change, temporary, interactive and kinetic structures would have found a receptive audience at the Architectural Association and traction within the experimental discourses around architecture in the 1960s. ${ }^{17}$ The South Bank event (1961) had made Metzger something of a celebrity figure amongst architecture circles; Cedric Price borrowed a copy of Harold Liversidge's film of the performance, and it was the architect theorist Royston Landau who invited Metzger to lecture at the Architectural Association. The young student Charles Jencks later borrowed Metzger's lecture notes. ${ }^{18}$

Metzger developed various detailed models and proposals for monumental public art works on an architectural scale; perhaps the most ambitious of which was Five Screens with Computer (1965-9). He introduced it to his audience at the Architectural Association thus: "This sculpture consists of five walls or screens about thirty feet in height and forty feet long and two feet deep. They are arranged about twenty-five feet apart and staggered in plan. I envisage these in a central area between a group of three very large densely populated blocks of flats in a country setting" (Metzger 2015, 19). Each wall would contain ten thousand uniform elements - made of steel, plastic or glass - which would be randomly ejected from the wall to crash onto the ground below, over a period of ten years. A computer programme would be devised to control the ejections. The siting and scale of this sculpture were critical factors in achieving the desired physical and psychological impact. Technological, architectural auto-destructive art mirroring "the disintegrative effects of machinery and of life in vast built-up areas on the person" (Metzger 1960). He was unequivocal in challenging his audience to raise their game: 
"I have said that people must use their profession to change society. Architecture and town planning are among the most exposed professions today. You can go on confined by millenniums of traditions and taboos and help build our self-destructive society. You have the alternative of using architecture to unhinge these traditions and taboos. Instead of going on with the interminable large scale construction and competition, you can find from within the core of the discipline, concepts and forms that will shatter existing mental and physical structures in architecture as radically as auto-destructive art has done in art. Architecture can be used to undermine values, to protest,

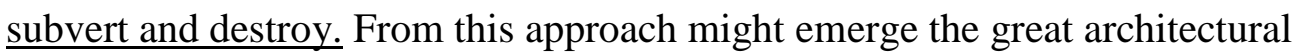
form you are no doubt seeking” (Metzger 1965, 22)

It is perhaps unsurprising that architecture students assisted Metzger with the South Bank demonstration, and an architecture student who organised Metzger's "Chemical Revolution in Art" lecture in Cambridge (putting Metzger up in his college room and playing an instrumental role in Metzger's first liquid crystals experiments). Metzger also called on architects to help him develop design studies for Five Screens with Computer. He worked with Richard J. Stibbs, a research assistant at the Centre for Land Use and Built Form Studies, a research group set up by Leslie Martin within the Architecture Department at the University of Cambridge, to produce a number of plotter drawings as design studies for Five Screens with Computer. The drawings were programmed in FORTRAN 66 by Anthony W. Nutbourne and created on TITAN, the University of Cambridge Mathematics Department's mainframe computer. ${ }^{19}$ (Fig. 7 here) Metzger continued to present such design studies in lectures 
and as contributions to exhibitions such as Jasia Reichardt's Cybernetic Serendipity at the ICA in 1968 and Event One at the Royal College of Art in $1969 .^{20}$

\section{Post-manifesto}

In 1966, Metzger expanded his efforts to mobilise and inform, and to reach new audiences. In the space of six months, he organised two interdisciplinary symposia. The first, a modest day-long event in May 1966 at Ravensbourne College, was entitled "Creation, Destruction and Chemical Change." It involved mostly artists and writers, including Mark Boyle, Dom Sylvester Houédard, John Latham and Ivor Davies. Hot on it's heels, in September 1966, Metzger and the poet John Sharkey organised the Destruction in Art Symposium (DIAS): a ground-breaking, two-day symposium and month-long programme of events which ran from 31 August - 30 September 1966.

The first press release for DIAS, which went out in April 1966, declared their aim "to create an opportunity for artist, writers, psychologists, sociologists, and other scientists to meet and exchange ideas. DIAS aims to assemble the maximum amount of information on the new art forms and related topics, and to make this information freely available." (Metzger 1966a) According to Kristine Stiles, "Metzger sought to make DIAS an interdisciplinary framework for discourse related to the phenomena of destruction in the biological, economic, social, psychological and aesthetic sense. The dialogue that Metzger hoped to establish at DIAS would include professionals among all disciplines in order to prevent it from being mired in a narcissistic ghetto of avantgarde experimentalism" (Stiles 1987, 13).

The majority of its participants were pioneers of interdisciplinary practice, and included a high proportion of visual artists who had been instrumental in the 
development of event-structured art that drew on dance and theatre techniques, such as Happenings, Fluxus, Events, Actions and Concrete Poetry. Metzger had also assembled an Honorary Committee, representing a network of intersecting concerns from counter culture and concrete poetry to nuclear war. ${ }^{21}$ In order to avoid any conflict with his role as organiser, Metzger gave himself the title of honorary secretary, and did not participate as an artist, except to chair discussions. In his opening speech at the symposium, Metzger listed the following topics for discussion “ART: Architecture, film, Happenings, language, music, plastic arts, theatre. SOCIETY: Atmospheric pollution, creative vandalism, destruction in protest, planned obsolescence, popular media, urban sprawl/overcrowding, war. SCIENCE: Biology, economics, medicine, physics, psychology, sociology, space research” (Metzger 1966b).

Metzger envisaged DIAS as a catalyst for a movement; follow-up events were planned and Metzger produced at least two DIAS bulletins in the months following the symposium. The theme of DIAS keyed into debates within the anti-psychiatry and counter-culture movements, while in many ways its interdisciplinary emphasis, nonhierarchical structure, dedicated social aim and associations with various radical education and political groups paved the way for the Dialectics of Liberation Congress which was organised by Joe Berke ten months later at the Roundhouse in London, in July $1967 .{ }^{22}$ Berke was a key figure in the anti-psychiatry movement who had also delivered a paper at DIAS.

Rather than mobilising the masses, the momentum of DIAS and Dialectics gradually dissipated. After the performance by Hermann Nitsch at St Brides Institute on Fleet Street, on 15 September 1966, Metzger and his fellow organiser John Sharkey were charged with 'having unlawfully caused to be shown a lewd and 
indecent exhibition. ${ }^{23}$ Their trial at the Old Bailey coincided with the Dialectics congress although Metzger managed to attend part of the congress and it was there he met a young student, John Plant, who invited Metzger to take part in an arts festival he was organising at the University of Swansea in the new year.

When Metzger arrived in the first week of January 1968, ten days before the festival opened, he found a newly-built filtration lab in the Chemical Engineering Department, and with Plant's help, enlisted the support of the departmental technicians, and moved in. The lab facilities included powerful water jets, a continuous supply of compressed air, natural and artificial light, heat, and access to various chemical compounds and minerals. Using the resources at hand, Metzger made an 'exhibition ${ }^{24}$ of ephemeral, kinetic sculptures, "Material/transforming art" that he created and controlled in the same way that he had animated the light projections in his lecture/demonstrations. (Fig. 8 near here)

In the broadsheet produced to accompany the exhibition, Metzger defined his role as a coordinator - implying a rather more objective relationship to the art than that of the artist. He choreographed interactions between elements such as water, heat and graphite to create aesthetic experiences based on physical phenomena such as the Leidenfrost effect, or direct currents of compressed air to make large panels of polystyrene 'levitate'. Plant would bring groups of visitors to the lab both during the day and at night, and Metzger would orchestrate a variety of interactive aesthetic experiences for his audience. Metzger described his intervention as "a purely scientific construction for purely artistic purposes" (Phillpot and Metzger 1997b); as he had put it, "various forms of kinetic art give the opportunity for studying different aspects of spectator response to works of art." $(1965,25)$ The installation in Swansea reimagined art as a scientific study of perceptual experience. Metzger called it "a 
landmark event in the history of British kinetic art that went almost unnoticed at the time" (Phillpot and Metzger 1997b).

Three years earlier, in his lecture/demonstration at the Architectural Association, Metzger had presented an argument for kinetic art, auto-destructive art and material/transforming art as forms of visual research, relating aspects of the work to "some concepts of quantum theory," physics, and processes within the autonomic nervous system (Metzger 1965, 23-26). In this, he revealed close affinities with the international New Tendencies movement (1961-73), which had declared "art as visual research" a core concern (Rosen, 2011; Medosch 2016).

There was, indeed, significant overlap between Metzger's concerns and the political and aesthetic aims of the New Tendencies movement, which was broadly aligned with the post-war New Left. Artists and theorists involved with New Tendencies also deployed the form of the manifesto, in which they rejected "the unique and isolated artist, the cult of the personality, the myth of creation, the production of unique works of art, and art's dependence on the market place" (Groupe de Recherche d'Art Visuel, 1961). The movement espoused experimental research methods from Gestalt psychology, a holistic, experimental form of psychological research, and combined it with the idea of liberating the viewer from alienation. This again would have informed Metzger's interest in psychology and his interaction with psychologists at DIAS (1966) and the Dialectics of Liberation (1967). The notion of alienation in the social context of the time, characterised by rapid modernisation processes or "automation" in industry, also chimed with Metzger's anti-capitalist stance and the research that directly followed his work in Swansea and led to the twopart article "Automata in History" (1969) on the relationship between automata and society. 
In February 1968, Metzger returned to London to begin work on a "Automata in History," which had been commissioned by Peter Townsend for Studio International. The article Metzger to revisit the central premise of his earlier manifestos, namely the threat of destruction through the misuse of developing technologies and the problematic relationships between art, technology and capitalism. He did so this time through thorough and painstaking scholarly research, and produced a historical survey of automata in societies across Asia and Europe from prehistory to the twentieth century.

Part I, published in March 1969, focused largely on the position of artists in relation to technology in the twentieth century, contextualised within a social history of automata and mechanical art in which "mathematicians, scientists, artists, engineers, musicians, priests, astronomers, princes, skilled men from scientific instrument makers to goldsmiths, worked in collaboration." From the "inter-media" endeavours that produced "clocks and automata in ancient China, Greece, Islam, India, medieval and renaissance Europe [that] conveyed information about advanced technology" and played "a prominent role in certain societies" to the Bauhaus, which despite aiming for "social change through art and technology," supplied "good design" and "helped to cement Capitalism" instead, Metzger underlined the social impact of artists engaging with technology in order to highlight the stakes in a postwar context.

"Whilst more and more scientists are investigating the threats that science and technology pose for society, artists are being led into a technological kindergarten," wrote Metzger. "It is a moral crisis and hinges on the artist's social responsibility. There is a tendency for the artist to submit to and be overwhelmed by the tremendous opportunity, challenge, excitement, and power of the new media. There exists a great 
danger that the artist will be eaten up by big business and manipulated by technology. That would be catastrophic." He summed up bluntly: "the artist who seeks to integrate with technology without realizing what is involved is behaving immaturely and dangerously." The 'scientist's backlash,' with its origins in "the revulsion and guilt felt by leading physicists over the detonation of the atomic bombs over Japan," offered an example to follow. "The revolutionary significance of [groups like The Atomic Scientists of Chicago] lies in having established the principle where each profession warns society about those dangers of which it has specialized knowledge. It is evident that of all artists, those engaged with science and technology must take a lead in this crucial new form of social agitation."

Metzger set out a role for the artist in contemporary research and industrial contexts, specifically "in the development of new forms of technology." Artists could act "as bearer of ideas, information, intuitions, and techniques and materials...serve as a stimulant and irritant...[and] disorient, undermine and re-route established, ritualised, ways of thinking and doing" (Metzger 1969a). The goal was clear to Metzger, who in his 1965 lecture, "The Chemical Revolution in Art" had declared "We are now faced with the imperative need to take one of the most radical steps in history: the conscious creation of new forms of science and technology that have been cleared, to some extent, of in-built destructive elements." (Metzger, 1965b)

Part II began with the statement: "One letter but thousands of years separate automaton from automation. The increased automation of life, and recent work in kinetic and technological art, demand and facilitate an involvement with automata. The further we are removed from their origin, the greater the chance of achieving both a comprehensive and detailed view of their history, and of evaluating their decisive significance in the development of science, technology, and art." In this text, Metzger 
charted the various roles of automata in societies as scientific tools, instruments of social control, traded goods and entertainment, highlighting correspondences between automata of the past and kinetic art of the present. "Alexandrian automata are close to current ideas of the random, feedback and automatic control. [...] The extensive use of chemical and fluid techniques in kinetic art during the past ten years brings this period into correspondence with Alexandria. Chemical, fluid, and biological exploration - in kinetic art, as in technology - is the most revolutionary direction now" (Metzger 1969b, 113). Metzger's history sought to demonstrate how "the principles of automata became internalised within society and technology" as the processes of industrialisation and urbanisation during the nineteenth century reshaped society: "The automated factory is the automata of antiquity writ large. (Metzger 1969b, 110).

It was around this time that Metzger became heavily involved in the 'Art and Science' and 'New Science' sub-groups of the British Society for Social Responsibility in Science (BSSRS). His view of the relationship between technology and capitalism coloured his ongoing activities and he continued to write on art and technology for a wide range of periodicals, from Peace News to the underground architecture journal Clip-Kit. "The task of the artist committed to the use of computers and advanced technology," he wrote, "is to oppose the stasis in computer development caused by considerations of profit, and align himself with the scientists who are fighting the system from within" (Metzger 1970a). In April 1969, Metzger became the founding editor of PAGE, the bulletin of the newly formed Computer Arts Society, and in May 1969, Metzger travelled to the International Symposium on Computers and Visual Research in Zagreb, Yugoslavia, with the cybernetician Gordon Hyde and art and technology critic Jonathan Benthall, to deliver a manifesto 
"from London" announcing the launch of the Computer Arts Society (C.A.S.). They declared:

"Artists are increasingly striving to relate their work and that of the technologist to the current unprecedented crisis in society. Some artists are responding by utilizing their experience of science and technology to try and resolve urgent social problems. Others, researching in cybernetics and the neuro-sciences, are exploring new ideas about the interaction of the human being with the environment. Others again are identifying their work with a concept of ecology, which includes the entire technological environment that man has imposed on nature. There are creative people in science who feel that the resolution of the man/machine problem lies at the heart of making the computer the servant of man and nature. Such people welcome the insight of the artist in this context, lest we lose sight of humanity and beauty" (Benthall, Hyde and Metzger, 1969).

Metzger oversaw the first 27 issues of PAGE before stepping down in December 1972. Initially a modest, double-sided A4 sheet, PAGE's primary purpose was "to encourage the creative use of computers in the arts and allow the exchange of information in this area" (PAGE 2, May 1969). Much of its limited space was devoted to news, reviews and listings. The fact that Metzger did most of the reviewing ensured that he became extremely well informed of new developments and technologies. This allowed him to make experimental artworks using early Plotters (inkjet printers), and to write and lecture on creative applications of the technology, although PAGE was not merely a means for Metzger to connect with scientists and technologies. ${ }^{25} \mathrm{He}$ quickly established a distinctive editorial position, introducing whimsical features such as "Background to Computer Arts," inviting other artists and international 
groups to edit individual issues, and consistently drew attention to issues associated with the social impact of technology (PAGE 24 [July 1972] simply included a fullpage reproduction of the Sunday Times cover with a picture of a limb-less young victim of the Vietnam war).

As it was a small, labour-intensive operation, Metzger assumed the roles of designer, typesetter and printer as well as editor and occasional contributor. This model presented him with a template to experiment with, and allowed Metzger the freedom to experiment - indeed at times Metzger was operating as much as an artist and activist as editor. PAGE 11, for example, featured an article by Metzger entitled "Social Responsibility and the Computer Professional. The Rise of an Idea. Part I" (Metzger 1970d). (Fig.9 near here) The front page was filled with columns of numbers, a comprehensive list that Metzger had compiled of every article and news item containing the term 'social responsibility' that had appeared to date in the communications of the Association of Computing Machinery and associated Journal of the Association of Computing Machinery, and the magazine Computers and Automation. As Samuel Dangel has noted, the article exploited the organisational conventions and visual qualities of a bibliography - another template, like the lecture and the bulletin, with specific methodologies, lexicons and functions, effectively appropriated by Metzger to open up a critically reflexive space within the form itself. $^{26}$

The launch of PAGE coincided with the inaugural meeting of the British Society for Social Responsibility in Science (BSSRS) in April 1969, which Metzger attended. He made a statement that led Maurice Wilkins to invite him to join an "Art and Science" splinter group that met on a monthly basis in Wilkin's laboratory at Kings College. The group also included the artist Conrad Atkinson; Jonathan 
Benthall, who at the time worked at the ICA and wrote a regular column on 'Art and Technology’ for Studio International; the science journalist David Dickson; Jerry Ravetz, who headed the Centre for History and Philosophy of Science at Leeds University; and 'Kit' Pedlar, who was head of the electron microscopy department at the Institute of Ophthalmology, University of London, and scientific advisor for the BBC on such programmes as Tomorrow's World and Dr Who.

The momentum of BSSRS spawned several weekend-long meetings of a "New Science" group at Pedlar's home in the summer of 1970. Invitees were largely left-leaning scientists and intellectuals, including Ravetz, Dickson and Peter Harper, founder of the Centre for Alternative Technology. Metzger was the only artist present. Discussions centred around the crisis of confidence and ethical issues in science, the impact of the H-bomb, and revolution. Despite a heady mood of "apocalyptic ferment ${ }^{\prime 27}$ the group did little, but produced a manifesto, Harmony (1970), which remained unpublished until recently (Fisher, 2014). Metzger was still hopeful that revolutionary change through interdisciplinary effort was possible. He continued to attend BSSRS events such as The Social Impact of Modern Biology conference in November 1970, where he made the following statement: “...We are faced by issues that are deeper than the political level. The problem also resides in the particular fabric of science and technology - not merely in its social applications. It seems to me - and I am speaking as an artist - that the most challenging and profound, and ultimately the most constructive research activity in science, is that effort to establish new and revolutionary insights into the nature of science and technology as it has developed in different cultures in the past thousands of years."28

The early '70s saw Metzger become increasingly engaged with problems of environmental pollution, in projects such as Stockholm June, a proposal drafted in 
response to the first UN Environmental Conference in Stockholm in 1972, and Karba, which was commissioned by Harald Szeeman for Documenta 5 and included in the exhibition catalogue, but not actually realized. The Architectural Association hosted an exhibition of Metzger's Unrealizable Disintegrative Architecture and Other Projects in April 1972. Unrealizable was becoming a theme. Despite this, he continued to lecture on the subject of "Ethics of the Art/Science/Technology Link" and contribute to group exhibitions.

In 1974, Metzger was invited to take part in the exhibition "Art Into Society/Society Into Art" at the ICA, London. In the exhibition catalogue, in lieu of a material contribution, he chose to call for an art strike: Years Without Art 1977-80. Art no longer held the promise of revolution. He gave the following reason: "Artists engaged in political struggle act in two key areas: the use of their art for direct social change; and actions to change the structures of the art world. It needs to be understood that this activity is necessarily of a reformist, rather than revolutionary, character. Indeed, this political activity often serves to consolidate the existing order, in the west, as well as in the east." He continued: "The use of art for social change is bedevilled by the close integration of art and society. The state supports art, its needs are as a cosmetic cloak to its horrifying reality, and uses art to confuse, divert and entertain large numbers of people. Even when deployed against the interests of the state, art cannot cut loose from the umbilical cord of the state. Art in the service of revolution is unsatisfactory and mistrusted because of the numerous links of art with the state and capitalism." "Deep surgery," as he called it, was necessary. "As the 20th century has progressed, capitalism has smothered art - the deep surgery of the years without art will give art a new chance. ${ }^{, 29}$ Metzger went on strike alone. 


\section{References}

Benthall, Jonathan, Gordon Hyde and Gustav Metzger. 1969. "Zagreb Manifesto"

London, 4 May 1969 in Studio International vol.177 no.911, London June 1969.

Dangel, Samuel and Sören Schmeling, eds. 2012. Gustav Metzger: Years without Art.

Freiburg, Modo Verlag.

Fisher, Elizabeth. 2014. Gustav Metzger: Lift Off! Cambridge, University of Cambridge Kettle's Yard.

Ford, Simon. 2003. “Technological Kindergarten.” MUTE Vol. 1, no. 26

Summer/Autumn 2003, http://www.metamute.org/editorial/articles/technologicalkindergarten. Accessed 26.9.2016.

Gropius, Walter. 1919. "Bauhaus Manifesto and Program” Staatlisches Bauhaus Weimar, April 1919.

http://mariabuszek.com/mariabuszek/kcai/ConstrBau/Readings/GropBau19.pdf. Accessed 23.11.16.

Groupe de Recherche d'Art Visuel. 1961. "General Propositions of the Visual Arts Research Group.” Trans. Davida Fineman. In Readings in Latin American Modern Art. Ed. Patrick Frank. New Have: Yale University Press, 2004: 161-163.

Houédard, Dom Sylvester. 1966. “Aesthetics of the Death Wish? Change as Creative Destruction: the Ravensbourne Symposium on Creation Destruction \& Chemical Change: Record and Comment.” London, Destruction/Creation, BM/DIAS.

Reichardt, Jasia (ed). 1968. Studio International. Cybernetic Serendipity. The Computer and the Arts. London 1968.

Lansdown, R. John, Jasia Reichardt, John Lifton, Ian Pickering, George Mallen et al. 1969. Event One. London, Computer Arts Society. 
Medosch, Armin, "Art as Visual Research: The Tendency in New Tendencies” in Journal for Research Cultures, issue 1. https://researchcultures.com/issues/1/art-asvisual-research.html Accessed 2.1.17.

Metzger, Gustav. 1959. “Auto-Destructive Art” First manifesto. London, 4 November 1959.

Metzger, Gustav. 1960. "Manifesto Auto-Destructive Art” Second manifesto.

London, 10 March 1960.

Metzger, Gustav. 1961. “Auto-Destructive Art, Machine Art, Auto-Creative Art.” Third manifesto. London, 23 June 1961.

Metzger, Gustav. 1962a. "Machine, Auto-Creative and Auto-Destructive Art" in Ark, Royal College of Art London, Summer 1962.

Metzger, Gustav. 1962b. "Manifesto World.” Fourth manifesto. London, 7 October 1962.

Metzger, Gustav. 1964. “On Random Activity in Material/Transforming Works of Art." Fifth manifesto. London, July 30, 1964. Published in Signals. Newsbulletin of the Centre for Advanced Creative Study, Vol.1, No.2, September 1964: 14. Metzger, Gustav. 1965. Auto-Destructive Art. Typescript of a lecture given at the Architectural Association, 24 February 1965. Third edition: London, Bedford Press 2015.

Metzger, Gustav. 1965b. "The Chemical Revolution in Art” published as "AutoDestructive Art" in Granta, 6 November 1965.

Metzger, Gustav. April 1966a. First DIAS press release.

Metzger, Gustav. 1966b. Abstract of DIAS opening remarks, excerpted in: Studio International issue 174, December 1966: 238. 
Metzger, Gustav. 1966c. “Auto-Destructive Art.” Anarchy Magazine no. 64, London June 1966.

Metzger, Gustav. 1966d. "The possibility of Auto-Destructive Architecture.” Clip-Kit Studies in Environmental Design no. 2, London 1966.

Metzger, Gustav. 1966e. “An Overwhelming Concern with Shelter!” Peace News no. 2, London September 1966.

Metzger, Gustav. 1968. "Theory of Auto-Destructive Art," Calendar of the AntiUniversity London. 1968.

Metzger, Gustav. 1969a. "Automata in History Part I" in Studio International vol. 177 no.909, March 1969: 107-109.

Metzger, Gustav. 1969b. “Automata in History Part II” Studio International October 1969: 109-117.

Metzger, Gustav. 1970a. "Notes on the Crisis in Technological Art" and "4 Manifestos by Gustav Metzger.” Klepht no.1. Swansea, January 1970.

Metzger, Gustav. 1970b. "Kinetics.” Art and Artists vol.5 no. 6, London September 1970.

Metzger, Gustav. 1970c. "Design Studies.., a talk given by Metzger at New Tendencies 4." Tendencije 4. Zagreb, 1968-1969. Computers and Visual Research. Zagreb, Galerija Suvremene Umjetnosti, 1970.

Metzger, Gustav. 1970d. "Social Responsibility and the Computer Professional. The Rise of an Idea. Part I,” PAGE 11, October 1970.

Metzger, Gustav. 1970. "New Ideas in Plotter Design Construction and Output," unpublished lecture at Computer Graphics '70.

Metzger, Gustav. 1971. "Five Screens with Computer. Computer Graphic Aspects of a Sculpture Project” in Computer Graphics '70. Plenum Press, London 1971. 
Metzger, Gustav. [1969] 1971. "Untitled paper on Theme Number Three.” Computer and Visual Research Symposium, Zagreb 1969, in Bit International no. 7, edited by Boris Kelemen and Radoslav Putar. Zagreb, Galerije grada Zagreba: 26-33. Peyton-Jones, Julia and Hans Ulrich Obrist (eds). 2009. Gustav Metzger Decades 1959-2009, Walter König, Köln.

Phillpot, Clive and Gustav Metzger. 1997a. Artists' Lives Recording. British Library ref C466/292.

Phillpot, Clive and Gustav Metzger. 1997b. Artists' Lives Recording. British Library ref C466/50/BSZZ.

Phillpot, Clive and Gustav Metzger. 1997c. Artists' Lives Recording. British Library ref C466/50/APZZ.

Rosen, Margit (ed). 2011. A Little Known Story about a Movement, a Magazine, and the Computer's Arrival in Art: New Tendencies and Bit International, 1961-73.

Cambridge, Mass., MIT Press.

Stiles, Kristine. 1987. "The Destruction in Art Symposium (DIAS): The Radical Social Project of Event-Structured Live Art" Ph.D. History of Art, University of California, Berkeley.

Walker, John A. 2002. Left Shift, Radical Art in 1970s Britain London, IB Tauris \& Co.

Wilson, Andrew. 2008. “Gustav Metzger's Auto-Destructive/Auto-Creative Art: An Art of Manifesto, 1959-69” in Third Text, vol. 22, Issue 2, March 2008: 177-194.

Wilson, Rt Hon Harold, MP. 1963. "Labour's Plans for Science” Speech given at the annual Labour Party Conference, Scarborough, 1 October 1963. London, Victoria House Printing Company. http://nottspolitics.org/wpcontent/uploads/2013/06/Labours-Plan-for-science.pdf Accessed 25.9.2016 
${ }^{1}$ Activist art was to emerge as a coherent and identifiable set of practices in the 1960s, informed by the expanded fields of conceptual and performance art practice. Metzger introduced his theory of Auto-Destructive Art in his first manifesto, 4 Nov 1959. By 1965, Metzger was describing auto-destructive art as "a comprehensive theory for action in the field of the plastic arts in the post-second world war period. The action is not limited to theory of art and the production of art works. It includes social action. Auto-destructive art is committed to a left-wing revolutionary position in politics, and to struggles against future wars." (Metzger 2015, 1)

${ }^{2}$ Szekely was a Hungarian linguist who held professorships in philosophy and experimental psychology. He founded the International Biogenic Society with French novelist and mystic Romain Rolland in 1928.

https://en.wikipedia.org/wiki/Edmund_Bordeaux_Szekely_Accessed 20.12.2016

${ }^{3}$ Reich was an Austrian psychoanalyst and student of Sigmund Freud, a Marxist political theorist, and inventor of the Orgone Energy Accumulator.

${ }^{4}$ Bomberg took an overtly political position as an artist. According to Kristine Stiles, Bomberg recommended to the London Group in 1937 that they prohibit reactionary groups from exhibiting, join Artists International Association and Surrealist groups in supporting anti-Fascism in politics and art, grant funds for the Spanish medical aid, and give honorary membership to left wing poets and writers. (Stiles 1987, 66-67) ${ }^{5}$ Metzger was a founder member of the Committee of 100 along with Bertrand Russell, Michael Randle, Ralph Schoenman and others. The group used mass nonviolent resistance and civil disobedience as a form of direct action. According to Christopher Driver, Metzger and Schoenman gave the organisation its name, as a reference to the medieval Guelph Council of 100. 
https://en.wikipedia.org/wiki/Committee_of_100_(United_Kingdom)\#cite_note-

Driver-3, accessed 30 July 2016.

${ }^{6}$ Metzger, Gustav “Auto-Destructive Art” First manifesto. London, 4 November 1959.

${ }^{7}$ Ibid.

${ }^{8}$ The University of Cambridge Annual Rede Lecture, Senate House, 7 May 1959.

Metzger described Snow's lecture as a decisive moment both for his own

development and in the wider cultural context of the 1960s. Conversation with the author, May 2014.

${ }^{9}$ According to Stiles, Reichardt also invited Metzger to participate, along with the philosopher Stephan Themerson, the physicist David Bohm, and an art therapist, in an evening of discussion and presentations on Auto-destructive Art at the ICA in 1961, but the event was cancelled. (Stiles 1987, 35) At the ICA, Reichardt curated numerous interdisciplinary exhibitions including the seminal Between Poetry and Painting (1965) and Cybernetic Serendipity (1968).

10 "It is, of course, a cliché that we are living at a time of such rapid change that our children are accepting as part of their everyday life things which would have been dismissed as science fiction a few years ago. We are living perhaps in a more rapid revolution than some of us realise. The period of 15 years from the last time we were in Scarborough, in 1960, to the middle of the 1970s, will embrace a period of technological change, particularly in industrial methods, greater than in the whole industrial revolution of the last 250 years. When you reckon, as it is calculated, that $97 \%$ of all the scientists who have ever lived in the history of the world since the days of Euclid, Pythagoras and Archimedes, are alive and at work today, you get some idea of the rate of progress we have to face...we are re-defining and we are re-stating our 
Socialism in terms of the scientific revolution... The Britain that is going to be forged in the white heat of this revolution will be no place for restrictive practices or for outdated methods on either side of industry." (Wilson 1963)

${ }^{11}$ The first public demonstration of auto-destructive art took place at Temple Gallery, London on 22 June 1961.

${ }^{12}$ Metzger quoted in Peyton-Jones and Obrist, 2009: 25.

${ }^{13}$ Wilson's article draws particular attention to the central role of the 'manifesto-asform' in Metzger's early work: "Metzger linked his production of manifestos with the form of the Lecture/Demonstration - the Lecture/Demonstration being a performative realisation of the manifesto to explain and declare the aims and beliefs underpinning auto-destructive art and show clearly its relevance and meaning to a contemporary audience, while at the same time remaining apart from the structures of the art market - there being no by-product, nothing to sell."

${ }^{14}$ Conferences have been organised and MA theses written on the subject. See for example: http://www.e-flux.com/announcements/between-art-and-academia-lectureperformance/, http://thepublicschool.org/node/29191; http://www.theoffice.li/htm/lecture.htm, http://gabrielledevietri.com/files/gdvmfafinal.pdf, https://verysmallkitchen.com/2011/12/20/kitchen-essay-artists-talking-at-thedoubting-interface/ and Milder, Patricia, "Teaching as Art: the contemporary lecture performance" Performance Art Journal 97 (2011): 13-27.

${ }^{15}$ Metzger quoted in Stiles (1987): 170.

${ }^{16}$ Stiles' interview with Robin Nicholson provides some insight into this critical meeting. According to Nicholson, Metzger had read the Scientific American article and "like a lot of artists only half understood what was being talked about but 
appreciated the potential." Nicholson and Metzger went to Feinstein's house for the first time the night before the lecture/demonstration. Stiles quotes Nicholson at length: “...none of us had met him before except through telephone calls and we had coffee and talked and things like that. Gustav talked about liquid crystals and this guy said, yes he was working on them. Then we discovered that he had a laboratory in his house. So we moved to the laboratory where one of the most amazing evenings of my life took place. The bloke had seen what Gustav was interested in and had been doing it all the time. But the scientist was only interested in it from a physical end. Gustav was over the moon. But in the way that he is, he was also completely out of control and was always burning himself and telling everyone not to worry when actually he was the only one that was in a stew. He was always picking up red-hot bits of glass. We definitely had the facility to put this thing in a slide projector and heat it up and project it in quite a small room. And it (the crystals) did do all the things they are meant to do - change constantly and everything else. Now we did this in the lab and it was 3 o'clock in the morning before we actually got it working. We were all very excited about it and the problem was how to get it to work the next evening at the lecture. It didn't work and the scientist didn't come and nothing went right. Stiles: you needed the scientist to make it work properly? Nicholson: Partly. By that stage I wasn't in a fit state to keep things cool. Stiles: Gustav didn't know how to do it?

Nicholson: Gustav is not very good at organising things like that, very precise physical conditions - the right temperature, you know, and so many things can go wrong. We were trying to do it with an ordinary projector." (Stiles 1987, 179). 
${ }^{17}$ The hypothetical also had currency; precedents included from the Air Architecture of Yves Klein \& Claude Parent (1961), Cedric Price's Fun Palace (1961) and Peter Cook’s Plug-in City (1964).

${ }^{18}$ According to Stiles, Jencks borrowed a copy of his writings while still a student; Price borrowed a copy of the film of the South Bank Demonstration and Metzger later discussed a project for a kind of meditation centre for people entirely based on liquid crystal. (Stiles 1987, 125)

${ }^{19}$ For more on TITAN, see "TITAN computer / Bridging the Cultures: Architecture, Models and Computers in 1960s Cambridge" by Prof. Dean Hawkes, also in this issue. Metzger also worked with a D. E. Evans to produce a computer-generated drawing entitled Design Study for Five Screens with Computer (1969) using an IBM 7094 II and a CalComp plotter 536. (Rosen 2011, 426)

${ }^{20}$ See Reichardt (1968) and Lansdown et al (1969).

${ }^{21}$ Members included the pioneering historian of art and technology Frank Popper; the concrete poet and Benedictine monk Dom Sylvester Houedard; experimental poet and manager of Better Books Bob Cobbing; the artist and writer John Sharkey, who was also gallery manager at the ICA at the time; Wolf Vostell, an early proponent of Happenings and Fluxus; Barry Miles, editor of the International Times and co-owner of Indica Gallery; Jim Haynes, co-founder of International Times who in September 1967 founded the Arts Lab alternative arts centre; Welsh artist Ivor Davies; Italian artist and writer Enrico Baj; Mario Amaya, American founding editor of Art and Artists magazine; Roy Ascott, a pioneer of cybernetics and telematics in art, and Metzger himself as honorary secretary. 
${ }^{22}$ The purpose of the Dialectics of Liberation Congress was "to demystify human violence in all its forms, the social systems from which it emanates, and to explore new forms of action." http://www.dialecticsofliberation.com. Accessed July 2016. ${ }^{23}$ According to Simon Ford (2003), on 19 July 1967 the court found Metzger guilty and he accepted a $£ 100$ fine rather than spend four months in jail.

${ }^{24}$ Extremes Touch: Material/transforming art co-ordinated by Gustav Metzger 22 January - 4 February, 1968.

${ }^{25}$ Metzger's writings on the subject include "New Ideas in Plotter Design Construction and Output," an unpublished lecture at Computer Graphics '70, and "Five Screens with Computer. Computer Graphic Aspects of a Sculpture Project" in Computer Graphics '70. London, Plenum Press 1971.

${ }^{26}$ Dangel uses the term "bibliographic method" to describe a technique used by Metzger in this article and subsequently as his contribution to the exhibition \& catalogue Art into Society - Society into Art. Seven German Artists at the ICA in 1974, published as Metzger, Gustav "The Art Dealer: A Bibliography” in Christos Joachimides, Norman Rosenthal (ed). Art into Society - Society into Art. Seven German Artists Institute of Contemporary Arts, London 1974: 79-86. See Gustav Metzger: Years without Art Samuel Dangel \& Sören Schmeling, eds. Modo Verlag 2012.

${ }^{27}$ Peter Harper, in conversation with the author, Feb 2014.

${ }^{28}$ Metzger's statement is recorded in Watson Fuller, ed. 1971. The Social Impact of Modern Biology, proceedings of a conference organised by the British Society for Social Responsibility in the Sciences, 26-28 November 1970. Routledge \& Kegan Paul, London 1971: 245. 
${ }^{29}$ Metzger, Gustav. 1974. "Years Without Art" in Art into Society - Society into Art: Seven German Artists edited by Christos Joachimides and Norman Rosenthal.

London, Institute of Contemporary Arts 1974: 79-86. 